\title{
Organophosphorus Compounds and MAPK Signaling Pathways
}

\author{
Tahereh Farkhondeh ${ }^{1}$, Omid Mehrpour ${ }^{1,2}$, Constanze Buhrmann ${ }^{3}$, \\ Ali Mohammad Pourbagher-Shahri ${ }^{1}$ (D), Mehdi Shakibaei ${ }^{3, *}$ and Saeed Samarghandian ${ }^{4, *}$ (D) \\ 1 Medical Toxicology and Drug Abuse Research Center (MTDRC), Birjand University of Medical \\ Sciences (BUMS), Birjand 9717853577, Iran; farkhondeh2324@gmail.com (T.F.); \\ omid.mehrpour@yahoo.com.au (O.M.); ali.pourbagher.shahri@gmail.com (A.M.P.-S.) \\ 2 Rocky Mountain Poison and Drug Safety, Denver Health, Denver, CO 80204, USA \\ 3 Musculoskeletal Research Group and Tumour Biology, Chair of Vegetative Anatomy, Institute of Anatomy, \\ Faculty of Medicine, Ludwig-Maximilian-University Munich, Pettenkoferstrasse 11, D-80336 Munich, \\ Germany; constanze.buhrmann@med.uni-muenchen.de \\ 4 Healthy Ageing Research Center, Neyshabur University of Medical Sciences, Neyshabur 9318614139, Iran \\ * Correspondence: mehdi.shakibaei@med.uni-muenchen.de (M.S.); samarghandians1@nums.ac.ir (S.S.)
}

Received: 20 May 2020; Accepted: 9 June 2020; Published: 15 June 2020

\begin{abstract}
The molecular signaling pathways that lead to cell survival/death after exposure to organophosphate compounds (OPCs) are not yet fully understood. Mitogen-activated protein kinases (MAPKs) including the extracellular signal-regulated protein kinase (ERK), the c-Jun NH2-terminal kinase (JNK), and the p38-MAPK play the leading roles in the transmission of extracellular signals into the cell nucleus, leading to cell differentiation, cell growth, and apoptosis. Moreover, exposure to OPCs induces ERK, JNK, and p38-MAPK activation, which leads to oxidative stress and apoptosis in various tissues. However, the activation of MAPK signaling pathways may differ depending on the type of OPCs and the type of cell exposed. Finally, different cell responses can be induced by different types of MAPK signaling pathways after exposure to OPCs.
\end{abstract}

Keywords: organophosphorus compounds (OPC); MAPK signaling pathway; oxidative stress; apoptosis; ERK; JNK; p38-MAPK

\section{Introduction}

There is evidence that organophosphate pesticides (OPs) contribute to the etiology of many diseases including neurodegenerative, cardiovascular, respiratory, gastrointestinal, diabetic, dyslipidemic, and kidney diseases [1]. In addition, oxidative stress usually acts as the main mechanism in the pathogenesis of various diseases. In particular, inflammatory stimuli can synergistically enhance the influence of oxidative stress in different tissues [2]. Several researchers have pointed out that there is a correlation between OPs and the activation of signaling pathways for oxidative stress through the production of reactive oxygen species (ROS) [3]. ROS leads to further tissue damage via induction of lipid peroxidation, protein oxidation, and cell apoptosis [4].

Oxidative stress-induced by OP exposure can stimulate the mitogen-activated protein kinase (MAPK) signaling pathway in the tissue [3]. MAPK modules are key players of intracellular signal transduction with major roles in several physiological processes [5]. There are three subfamilies of these serine/threonine kinases in mammals, including extracellular responsive kinases (ERKs), c-Jun N-terminal kinases (JNKs), and p38-MAPKs, which can be activated by various types of OPs [6]. Activation of ERK, JNK, and p38 kinase in response to oxidative stress via ROS production has both a survival-promoting and a proapoptotic effect [7]. 
The activation of phospholipase C, gamma (PLC-gamma), and the proto-oncogenic tyrosine-protein kinase c-Src (c-Src) phosphorylate Ras and Raf by ROS both directly and indirectly activates ERK signaling [8].

ERK, one of the main signaling cassettes of the MAPK signaling pathway, contributes to the modulation of meiosis and mitosis functions in differentiated cells. In mammals, ERK consists of ERK 1/2, ERK3/4, ERK5, ERK7, and ERK8 classes. The ERK family plays the main role in the regulation of cell growth cycles, survival, and differentiation under normal and pathological conditions [8]. Activated ERK has negative and positive influences on the regulation of ROS production indirectly through p22phox induction, which increases ROS production; Nrf2 activation subsequently increases the expression of anti-oxidant components [9]. In addition, ROS leads to the activation of the apoptosis-signal-regulating kinase 1 (ASK1) through the activation of thioredoxin (Trx) and protein phosphatase 2C cDNA (PP2C epsilon). They block the inhibition of ASK1 and induce PP2B activation that positively regulates ASK1. Finally, the activated ASK1 stimulates the JNK and p38-MAPK signaling pathways [10] and JNK signaling in response to oxidative stress promotes either survival or proapoptotic pathways in cells [10]. In addition, the JNK signaling pathway has been reported to induce cell survival through forkhead box (Fox) activation, an increase in antioxidant production, and SIRT1 activation leading to inhibition of the p53-dependent signaling pathway [10]. Controversially, the JNK signaling pathway induces apoptosis in the cytoplasm and nucleus by activation of proapoptotic molecules and by preventing the activation of antiapoptotic molecules in the cytoplasm [10]. Furthermore, the JNK signaling pathway in the cell nucleus induces the activation of several transcription factors, which leads to an increase in proapoptotic gene expression [10]. In addition, the stimulated p38-MAPK signaling pathway enters the cell nucleus and promotes phosphorylation of the transcription factors of the activating transcription factor 2 (ATF2) and the protein binding the cAMP response element (CREB) by activating mitogen- and stress-activated protein kinases 1 and 2 (MSK1/2) [11]. Subsequently, ATF2 and CREB induce the expression of several proapoptotic genes, which subsequently lead to apoptosis [11].

This review was intended to evaluate and show the influence of OPs on the activation of the MAPK signaling pathway by oxidative stress and the association of the activated pathway with various diseases.

\section{General Characteristics of Organophosphorus Compounds}

It has been shown that organophosphorus compounds (OPCs) are organic compounds consisting of a phosphoryl $(\mathrm{P}=\mathrm{O})$ bond or a thiophosphoryl $(\mathrm{P}=\mathrm{S})$ bond, and several OPCs with different chemical, physical, and biological properties are commercially used. Furthermore, most of them are dissolved in oils and only a little in water, and the classification of OPCs is quite complex. There is therefore no uniform classification system for them. Indeed, OPCs derived from phosphoric acid and phosphonic acid derivatives usually have anti-cholinesterase activity, whereas OPCs derived from phosphonic acid do not have this property [12]. Examples of OPCs are the following: 1. insecticides such as diazinon (DZN), malathion, parathion, chlorpyrifos (CPF), dichlorvos, fenthion, and ethion; 2 . nerve gases such as sarin, soman, tabun, and VX; 3. ophthalmic agents such as isofluorophate and echothiophate; 4. anti-helminthic agents such as trichlorfon; and 5. herbicides such as tribufos (DEF) and merphos [13]. To qualify OPCs as an insecticide, it is necessary to be effective at low doses and OPCs should also have a low toxic effect on humans and animals. Most OPCs are in liquid form with different vapour pressures at $20^{\circ} \mathrm{C}$. They are used as liquid sprays or granules for agricultural purposes, and they are broken down by the hydrolysis process, which produces water-soluble products [14]. The toxicity of most OPCs is high, oral $\mathrm{LD}_{50}$ for humans is between 0.5 and $5 \mathrm{~g} / \mathrm{kg}$, and oral or respiratory exposure to 10 to $200 \mathrm{mg}$ parathion is fatal for adults [12]. However, it has been suggested that water-soluble products are nontoxic at concentrations for practical applications.

The estimated lethal doses of DZN, malathion, and parathion in humans are $25 \mathrm{~g}, 60 \mathrm{~g}$, and 10 to $200 \mathrm{mg}$ respectively [15]. Interestingly, it has been reported that, in developing countries, poisoning by OPCs is one of the most common types of poisoning leading to hospitalization [16]. The traditional 
approach suggested that the clinical symptoms of acute OPC intoxication were related to their effects on muscarinic, nicotinic, and CNS receptors. The general exposure to OPCs was usually through the consumption of food residues or the working environment. Moreover, OPCs can enter the body through ingestion, inhalation, or the skin. The metabolism of OPCs is usually by oxidation, hydrolysis, demethylation, and/or glucuronidation, and the oxidation of OPCs can lead to the formation of products with lower or higher toxic activity. It is known that the majority of OPCs is rapidly degraded and that this compound is mainly excreted in urine and, to a lesser extent, in feces. Although OPCs are not stored in the body for long, some of them are very lipophilic and are deposited in the fatty tissue for several days. Moreover, the binding of OPCs to acetylcholinesterase (AChE) in plasma and red blood cells are the main mechanisms of acute and chronic toxicity in the nervous system, and the activity of cholinesterase in red blood cells indicates the severity of toxicity of OPCs [16].

Most symptoms of OP intoxication are caused by the stimulation of several muscarinic receptors, and tachycardia and hypertension are sometimes observed in acute intoxications associated with the cholinergic effects of OPs on the CNS, sympathetic ganglion synapses, or the adrenal medulla [17]. A few numbers of OPs lead to an "intermediate syndrome" and a delayed neuropathy without inhibitory effect on AChE activity. Importantly, the nervous, cardiovascular, and respiratory systems are the main target organs for OPCs and it has been found that OPs can also inhibit the activity of other esterases [18].

Many of the OPs have no tumorigenic effect in animals, but some of them could induce cancer in experimental models $[19,20]$. Teratogenic and mutagenic effects have been found for some OP compounds. Some drugs, including antihistamines, phenothiazines, CNS depressants, theophylline, barbiturates, aminoglycosides, and parasympathomimetic agents, may exacerbate the toxicity of OPCs [21]. Indeed, in most poisonings, the interaction between organophosphate enzymes and enzymes that are both stable and treated occurs over a long time [21]. The inhibited enzyme can reactivate spontaneously, its rates depending on the tissue and the chemical group bound to the enzyme [21]. Further, OPCs are used as chemical warfare agents, which have stronger toxicity than insecticides. However, the use of OPCs in high concentrations can cause a toxic effect similar to chemical warfare agents [22].

\section{Oxidative Effect of Organophosphate Pesticides is Mediated by MAPK Signaling}

Oxidative stress is caused by a disturbance of the balance between oxidative and antioxidative systems, which leads to an impairment of the antioxidative defense [23]. It has been pointed out that oxidative stress leads to oxidation of lipids, proteins, and DNA, which causes various pathological states [23-28]. OPs induce oxidative damage by attacking one of the three main MAPK subfamilies, including ERK, JNK, and p38-MAPK kinase. In this context, it has been shown that acute exposure of mouse diaphragm muscle cells to dichlorvos (DDVP) induces oxidative stress, as evidenced by a decrease in the activities of AchE, Quinone oxidoreductase-1 (NQO-1), heme oxygenase 1 (HO-1), paraoxonase1 (PON1), catalase (CAT), superoxide dismutase (SOD), and Nrf2 protein expression as well as an increase in malondialdehyde (MDA) levels in the cells [28]. Similarly, it was observed that subacute exposure to DDVP induced liver injury in mice by oxidative stress by downregulation of PON1 and Nrf2 gene expression. The study showed that DDVP increased MDA levels and decreased glutathione (GSH), SOD, and CAT activities in the liver [29]. Furthermore, Jahan and colleagues [30] pointed out the effect of monocrotophos (MCP) on MAPK signaling in mesenchymal stem cells from human umbilical cord blood, suggesting that MCP increased ROS production by activating the ERK/AP-1 signaling pathway. In this context, it was shown that tris(1,3-dichloro-2-propyl)phosphate (TDCPP) reduced Nrf2, SOD1, and SOD2 expression in a dose-dependent manner in human umbilical cord endothelial cells (HUVECs) [31]. Further, there is evidence that CPF is involved in the impairment of oxidative stress signaling pathways, including MAPK signaling. Indeed, in Drospphila melanogaster, CPF increased the phosphorylation of p38-MAPK and JNK [32]. Shou and colleagues [33] investigated the effect of $\mathrm{CPF}$ on oxidative damage in PC12 cells, suggesting that $\mathrm{CPF}$ induced oxidative and 
apoptotic damage by the interfering Nrf2 signaling pathway, as evidenced by an increase in ROS and MDA values and a decrease in SOD values. In addition, OPCs exerted an inflammatory effect in the different tissues by inducing inflammatory mediators such as tumor necrosis factor alpha (TNF- $\alpha$ ), interleukin-6 (IL-6), and IL-1 $\beta$. It was found that the inflammatory and oxidative effects of OPCs are due to activation of the MAPK signaling pathway [34]. In fact, oxidative stress can induce the expression of inflammatory master transcription factors such as the nuclear transcription factor kappa-B (NF-kB), which are the most important regulatory factors in the induction of pro-inflammatory gene products and inflammation. It has been suggested that $\mathrm{CPF}$ induces apoptosis by the initial induction of oxidative stress in SH-SY5Y cells and that CPF stimulated molecular pathways including p38-MAPK, JNK and ERK, NF- $\mathrm{KB}$, and TNF- $\alpha$. Moreover, it has been shown that CPF also induced the activation of apoptotic pathways by increasing NF- $\mathrm{kB}$. Therefore, oxidative damage of OPs is mainly mediated by stimulation of the MAPK signaling pathway [34].

\section{Apoptotic Effect of Organophosphorus Compounds Is Mediated by MAPK Signaling}

Apoptosis or programmed cell death is regulated also by the MAPK signaling pathways under stress conditions. Three conventional MAPK signaling pathways (ERKs, JNKs, and p38-MAPKs) play an important role in modulating the apoptotic pathway. Indeed, it was shown that activated JNKs and p38-MAPKs stimulate apoptosis cascades, while ERK1/2 plays an important protective role against apoptosis [35]. It has been suggested that the balance between growth factor-activated survival strategies and stress-activated death strategies affect cell death or survival. Numerous studies have pointed to the antiapoptotic effect of activated ERK1/2 and the proapoptotic effect of retained activated p38-MAPK and JNK. In this context, it has been shown that the MAPK and PI3K/Akt signaling pathway was upregulated by phoxim, leading to apoptosis and inhibition of protein synthesis in silkworms [36]. Esquivel-Sentíes et al. [37] evaluated the effects of diethyl dithiophosphate (DEDTP) on human CD4+ T lymphocytes. Indeed, in vitro exposure to DEDTP reduced the expression of CD25 and the concentrations of IL-2, which caused an impairment of cell proliferation. DEDTP stimulated the activation of ERK, JNK, and p38 as well as the nuclear factor of activated T cells (NFAT), resulting in a decrease in cell proliferation. Thus, OPCs are involved in the apoptotic signaling pathway by induction of the MAPK signaling pathway. Table 1 indicates OPC-induced several diseases mediated by MAPK signaling.

Table 1. Organophosphorus compounds induced several diseases mediated by Mitogen-activated protein kinase (MAPK) signaling.

\begin{tabular}{|c|c|c|c|}
\hline References & OPC(s)/Dose & Experimental Model & Findings \\
\hline [30] & Monocrotophos; 10,100 , and $1000 \mu \mathrm{M}$ & $\begin{array}{c}\text { Human Cord Blood } \\
\text { Mesenchymal Stem Cells }\end{array}$ & $\begin{array}{l}\text { Increased ROS production through the } \\
\text { activation of the ERK/AP-1 pathway }\end{array}$ \\
\hline [32] & $\begin{array}{c}\text { Chlorpyrifos; } 0.75 \text { ppm (diluted in } 1 \% \text { sucrose } \\
\text { solution) }\end{array}$ & Drosophila flies & $\begin{array}{l}\text { Increased the phosphorylation of p38 } \\
\text { and JNK; no changes in the content of } \\
\text { total forms of p38 and JNK }\end{array}$ \\
\hline [34] & Chlorpyrifos; 0-200 $\mu \mathrm{M} ; 0-24 \mathrm{~h}$ & SH-SY5Y cells & $\begin{array}{l}\text { Induced cell apoptosis via activation of } \\
\text { p38, JNK, and ERK }\end{array}$ \\
\hline [36] & Phoxim; $4 \mathrm{mg} / \mathrm{L}$ added to the diet & Silkworms & $\begin{array}{l}\text { Upregulated MAPK and PI3K/Akt } \\
\text { signaling pathway genes }\end{array}$ \\
\hline [37] & Diethyldithiophosphate; $1-50 \mu \mathrm{M}$ & Human CD4+ T lymphocytes & $\begin{array}{l}\text { Stimulated the activation of ERK, JNK, } \\
\text { and p38 and NFAT nuclear } \\
\text { translocation, leading to a decrease in } \\
\text { cell proliferation }\end{array}$ \\
\hline [38] & Chlorpyrifos; $0,25,50,100$, and $200 \mu \mathrm{M}$ & PC12 cells & $\begin{array}{l}\text { Induced apoptosis via activating the } \\
\text { p38, JNK, and ERK; activated caspase-3 } \\
\text { and cleavage of PARP }\end{array}$ \\
\hline [39] & Chlorpyrifos; 25,50 , or $100 \mu \mathrm{M}$ & SH-SY5Y cells & $\begin{array}{c}\text { Induced generation of ROS and } \\
\text { activation of MAPKs via expression of } \\
\text { phospho-Drp1 }\end{array}$ \\
\hline
\end{tabular}


Table 1. Cont.

\begin{tabular}{|c|c|c|c|}
\hline References & OPC(s)/Dose & Experimental Model & Findings \\
\hline [5] & Chlorpyrifos; $100 \mu \mathrm{M}$ & SH-SY5Y cells & $\begin{array}{l}\text { Induced apoptosis by producing ROS } \\
\text { and upregulating COX- } 2 \text { mediated by } \\
\text { JNK and p38 pathways, independent of } \\
\text { the activation of ERK } 1 / 2 \text { signaling }\end{array}$ \\
\hline$[40]$ & Chlorpyrifos; $10 \mu \mathrm{M}$ & Rat hippocampal neurons & $\begin{array}{l}\text { Phosphorylation of ERK } 1 / 2 \text { during } 96 \mathrm{~h} \\
\text { exposure; withdrawal after } 48 \mathrm{~h} \\
\text { exposure caused inhibition of ERK } 1 / 2 \\
\text { activation, leading to the delayed } \\
\text { cytotoxicity in primary rat hippocampal } \\
\text { neurons }\end{array}$ \\
\hline$[41]$ & Chlorpyrifos; $0-80 \mu \mathrm{M}$ & $\begin{array}{l}\text { Primary cortical neurons from } \\
\text { embryonic day } 17 \text { or neonates } \\
\text { rats }\end{array}$ & $\begin{array}{l}\text { Activation of the ERK } 1 / 2 \text { - and } \\
\text { JNK-induced apoptosis; activation of } \\
\text { the p38-MAPK prevented apoptosis }\end{array}$ \\
\hline [42] & Chlorpyrifos; $5 \mathrm{mg} / \mathrm{kg}$, daily & $\begin{array}{l}\text { Substantia nigra (SN) in young } \\
\text { adults at PND 11-14 }\end{array}$ & $\begin{array}{l}\text { Induced dopaminergic neuronal } \\
\text { damage in SN following the } \\
\text { inflammatory response activation } \\
\text { through NF-kB p65 and p38- MAPK } \\
\text { pathways in the nigrostriatal system }\end{array}$ \\
\hline [43] & Sarin; $80 \mu \mathrm{g} / \mathrm{kg}$ & Wistar rats & $\begin{array}{l}\text { In the first } 6 \mathrm{~h} \text { after exposure, fast } \\
\text { elevation in the activity of ERK } 1 / 2 \text { with } \\
\text { no change in JNK that temporarily } \\
\text { inhibited apoptosis }\end{array}$ \\
\hline [44] & $\begin{array}{l}\text { Sarin and Soman-like agents; } 4.0 \mathrm{mg} / \mathrm{kg} \text { body } \\
\text { weight; Intravenous injection }\end{array}$ & Wistar rats & $\begin{array}{c}\text { Neurotoxicity via activation of JNK } \\
\text { following tyrosine kinase } \\
\text { phosphorylation }\end{array}$ \\
\hline [45] & Soman; intramuscular administration; $60 \mu \mathrm{g} \mathrm{kg}^{-1}$ & Wistar rat cerebellum & $\begin{array}{l}\text { Elevated the expression of activated } \\
\text { p38-MAPK and c-myc at } 14 \text { days after } \\
\text { poisoning; c-jun and elk- } 1 \text { expressions } \\
\text { did not change at } 14 \text { days after } \\
\text { poisoning }\end{array}$ \\
\hline [46] & Soman; intramuscular administration; $60 \mu \mathrm{g} \mathrm{kg}^{-1}$ & Rat cerebellar Purkinje cells & $\begin{array}{l}\text { Elevated the expression of } \\
\text { phosphorylated p38-MAPK and c-myc } \\
\text { at } 14 \text { days after poisoning; both } \\
\text { activated elk- } 1 \text { and c-jun expressions } \\
\text { were not changed at } 14 \text { days after } \\
\text { poisoning }\end{array}$ \\
\hline $\begin{array}{l}{[47]} \\
{[48]}\end{array}$ & Mevinphos, bilateral injection, of $10 \mathrm{nmol}$ & $\begin{array}{l}\text { Rostral ventrolateral medulla } \\
\text { (RVLM) of rats }\end{array}$ & $\begin{array}{c}\text { No effect on ERK1/2 and the total } \\
\text { amount of JNK, p38-MAPK, MAP2K4, } \\
\text { and MAP2K6. } \\
\text { Increased the phosphorylation of } \\
\text { ERK1/2 in Thr202 and Tyr204 and JNK } \\
\text { in Thr183 and Tyr185, of p38-MAPK in } \\
\text { Thr180 and Tyr182, of MAP2K4 in } \\
\text { Ser257 and Thr261, and of MAP2K6 in } \\
\text { Ser207 and Thr211 in RVLM and also } \\
\text { ATF-2 in Thr71 and of c-Jun } \\
\text { in Ser73 death }\end{array}$ \\
\hline [49] & Mevinphos; $10 \mathrm{nmol}$; injected bilaterally & $\begin{array}{l}\text { Rostral ventrolateral medulla } \\
\text { (RVLM) of rats during brain } \\
\text { stem death }\end{array}$ & $\begin{array}{l}\text { Stimulated the phosphorylation of } \\
\text { ERK1/2 at Thr202 and Tyr204 }\end{array}$ \\
\hline [50] & Bis(pinacolyl methyl phosphonate); $600 \mu \mathrm{M}$ & Cultured rat astrocytes & $\begin{array}{l}\text { Induced ERK signaling cascade for the } \\
\text { induction of mitochondrial vacuolation }\end{array}$ \\
\hline [51] & Phenyl saligenin phosphate; $0-200 \mu \mathrm{M}$ & $\begin{array}{l}\text { Mitotic and differentiated } \\
\text { H9c2 cardiomyoblasts }\end{array}$ & $\begin{array}{l}\text { Induced cytotoxicity by activating } \\
\text { JNK } 1 / 2 \text { but not ERK } 1 / 2\end{array}$ \\
\hline [52] & Chlorpyrifos and dimethoate; $0-1000 \mu \mathrm{M}$ & Human dendritic cells & $\begin{array}{l}\text { Decreased the phosphorylation of Akt } 1 \text {, } \\
\text { Akt 2, Akt, and ERK } 2 \text { and caused } \\
\text { pulmonary complications.; no effect on } \\
\text { the p38 or the JNK }\end{array}$ \\
\hline [53] & Enantiomers of isocarbophos; $0-40 \mu \mathrm{M}$ & Human hepatoma cells & $\begin{array}{l}(-)-\mathrm{ICP} \text { caused modification in } \\
\text { Bax/Bcl-2 ratio and hepatotoxicity via } \\
\text { sustained activation of the JNK }\end{array}$ \\
\hline [54] & $\begin{array}{l}\text { Tributylphosphate and tris (2-butoxy ethyl) } \\
\text { phosphate; } 50,100 \text {, and } 200 \mu \mathrm{M}\end{array}$ & Human hepatoma cells & $\begin{array}{c}\text { Induced mitochondrial and } \\
\text { p53-mediated apoptosis via activated } \\
\text { JNK and TBP also affected ERK1/2 }\end{array}$ \\
\hline
\end{tabular}


Table 1. Cont.

\begin{tabular}{|c|c|c|c|}
\hline References & OPC(s)/Dose & Experimental Model & Findings \\
\hline [55] & Tris-(2-chloroethyl)-phosphate; 0.01 and $1 \mathrm{mg} / \mathrm{L}^{-1}$ & $\begin{array}{l}\text { Primary cultured renal } \\
\text { proximal tubule cells }\end{array}$ & Elevated the phosphorylation of JNK \\
\hline [56] & Chlorpyrifos; $3-250 \mu \mathrm{M}$ for 24,48 , and $72 \mathrm{~h}$ & $\begin{array}{c}\text { Human placental } \\
\text { choriocarcinoma (JAR) cells }\end{array}$ & $\begin{array}{l}\text { Activated the p38-MAPK signaling } \\
\text { pathway protected against cytotoxicity }\end{array}$ \\
\hline [57] & Chlorpyrifon-oxon; $50 \mu \mathrm{M}$ for $40 \mathrm{~min}$ & $\begin{array}{l}\text { Wild-type (CHOK1) and } \\
\text { human muscarinic } \\
\text { receptor-expressing Chinese } \\
\text { hamster ovary cells (CHO-M2) }\end{array}$ & $\begin{array}{l}\text { Activated the ERK 44/42 signaling } \\
\text { through P13-K, PKC, and MEK }\end{array}$ \\
\hline [58] & Chlorpyrifos-oxon; $0-100 \mu \mathrm{M}$ & $\begin{array}{l}\text { Chinese hamster ovary } \\
\text { (CHOK1) }\end{array}$ & $\begin{array}{c}\text { Increased the effect of diacylglycerol on } \\
\text { ERK } 44 / 42 \text { activation in dose and time } \\
\text { dependent manner }\end{array}$ \\
\hline [59] & Trichlorfon; $100 \mu \mathrm{M}$ & $\begin{array}{l}\text { Porcine trophectoderm (pTr) } \\
\text { and uterine luminal epithelial } \\
\text { (pLE) cells }\end{array}$ & $\begin{array}{c}\text { Temporarily activated JNK and } \\
\text { p38-MAPK; inhibition of JNK, } \\
\text { p38-MAPK, and ERK1/2 decreased the } \\
\text { proliferation in pTr cells }\end{array}$ \\
\hline$[60]$ & Chlorpyrifos; 5-100 $\mu \mathrm{M}$ & $\begin{array}{l}\text { Colorectal adenocarcinoma } \\
\text { H508 cells }\end{array}$ & $\begin{array}{l}\text { Caused colorectal adenocarcinoma } \\
\text { H508 cell growth via involvement of } \\
\text { EGFR/ERK1/2 signaling pathway }\end{array}$ \\
\hline$[61]$ & Chlorpyrifos; $50 \mu \mathrm{M}$ & $\begin{array}{l}\text { MDA-MB-231 and MCF-7 } \\
\text { human breast cancer cell lines }\end{array}$ & $\begin{array}{l}\text { Caused cell death through ERK1/2 } \\
\text { phosphorylation-mediated }\end{array}$ \\
\hline [62] & Chlorpyrifos; $0,25,50$, and $100 \mu \mathrm{M}$ & SH-SY5Y cells & $\begin{array}{l}\text { Caused protein kinase } 1 \text { stabilization on } \\
\text { the outer mitochondrial membrane; } \\
\text { resulted in an elevation in Parkin } \\
\text { recruitment from the cytoplasm to the } \\
\text { abnormal mitochondria; PINK1 } \\
\text { stabilization was modulated by } \\
\text { ROS-mediated activation of JNK and } \\
\text { ERK } 1 / 2 \text { signaling. }\end{array}$ \\
\hline [63] & Diazinon; $10^{-4}$ to $10^{-5} \mathrm{M}$ & NT2 cells & $\begin{array}{l}\text { Reduced the phosphorylated ERK-2 } \\
\text { dose-dependently; phosphorylation of } \\
\text { Raf-1 did not affect }\end{array}$ \\
\hline [64] & $\begin{array}{c}\text { Paraoxon: } 100 \mu \mathrm{M} \text {; Phenyl saligenin phosphate: } \\
0.01,0.1 \text {, and } 1.0 \mu \mathrm{M}\end{array}$ & SH-SY5Y cells & $\begin{array}{l}\text { Paraoxon elevated the activity of the } \\
\text { MAPK pathway; Phenyl saligenin } \\
\text { phosphate inhibited the activation of } \\
\text { the MAPK pathway }\end{array}$ \\
\hline [65] & Omethoate; $0.5,1$, and $2 \mathrm{mg} / \mathrm{kg}$, PO, 60 days & ICR male mice & $\begin{array}{l}\text { At high doses, increased the expression } \\
\text { levels of both NF-KB and p38 MAPK; at } \\
\text { medium doses, increased the expression } \\
\text { of p38-MAPK }\end{array}$ \\
\hline [66] & $\begin{array}{l}\text { Omethoate; } 1.5,3 \text {, and } 6 \mathrm{mg} / \mathrm{kg} \text { body through } \\
\text { gastric for } 2 \text { months }\end{array}$ & Wistar rats & $\begin{array}{l}\text { Increased the levels of MDA, TNF- } \alpha \text {, } \\
\text { and IL- } 6 \text { and decreased the activities of } \\
\text { SOD and GPx through activation of } \\
\text { JNK, p38 MAPK, and NF- } k B \text {, leading to } \\
\text { insulin resistance. }\end{array}$ \\
\hline [67] & Chlorpyrifos and cyfluthrin; $0,25,50$, and $100 \mu \mathrm{M}$ & $\begin{array}{l}\text { Primary human fetal } \\
\text { astrocytes }\end{array}$ & $\begin{array}{l}\text { Increased the levels of activated ERK1/2; } \\
\text { increased inflammatory markers IL-6 } \\
\text { and GFAP }\end{array}$ \\
\hline [68] & Diazinon; $15 \mathrm{mg} / \mathrm{kg}, \mathrm{PO}$ & Liver of rats & $\begin{array}{l}\text { Induced hyperlipemia and increased } \\
\text { levels of LDLr transcription through } \\
\text { inhibition of ERK pathway }\end{array}$ \\
\hline
\end{tabular}

Abbrivations: Akt: Protein kinase B, AP-1: Activator protein 1, COX-2: Cyclooxygenase-2, Elk-1: ETS Like-1, ERK: Extracellular signal-regulated protein kinase, GFAP: Glial fibrillary acidic protein, GPx: Glutathione peroxidase, ICP: Isocarbophos, iNOS: inducible nitric oxide synthase JNK: c-Jun NH2-terminal kinase, LDLr: Lipoprotein receptor, MAPKs: Mitogen-activated protein kinases, MEK: Mitogen-activated protein kinase kinase, NF-K $\beta$ : Nuclear transcription factor kappa- $\beta$, NO: Nitric oxide, PARP: Poly (ADP-ribose) polymerase, PI3Ks: Phosphoinositide 3-kinases, PKC: Protein kinase C, PKG: Protein Kinase G, PO: Per Os, PTr: Porcine trophectoderm, RVLM: Rostral ventrolateral medulla, Ser73: Phospho-c-Jun, SN: Substantia nigra, SOD: Superoxide dismutase, Thr180/Tyr182: Phospho-p38 MAPK, Thr261: Phospho-SEK1/MKK.

\section{Organophosphorus Compound-Induced Neurodegenerative Diseases are Mediated by MAPK Signaling}

Several members of the MAPK family, such as JNK, p38-MAPK, and ERK, are implicated in many neurodegenerative processes. The effects of OPCs on the MAPK signaling pathway-mediated neurodegenerative diseases have been reported in several scientific works of literature. OPCs disturb the balance between JNK, p38-MAPK, and ERK inducing apoptotic, oxidative, and inflammatory damages in neurons. Because exposure to $\mathrm{CPF}$ is more common among people, the majority of studies 
focused on the CPF neurotoxicity to study the impact of insecticides in the MAPK signaling pathways. In addition, it has been reported that $\mathrm{CPF}$ induces neuronal damage by activating three main pathways of MAPK including p38-MAPK, JNK, and ERK signaling. The effects of CPF on the MAPK pathways indicated that CPF has a major role in the induction of apoptosis, inflammation, and oxidative stress. The investigation on neurotoxic effects of CPF in PC12 cells indicated that treatment with 0, 25, 50, 100, and $200 \mu \mathrm{M}$ CPF induced dose-dependently apoptosis via activating the p38-MAPK, JNK, and ERK, suggesting that activated p38-MAPK, JNK, and ERK signaling pathways acted as death signals and also activated caspase-3 and poly(ADP-ribose) polymerase (PARP) cleavage [38]. Additionally, the induction of apoptosis by CPF in the dopaminergic neurons of PC12 cells through activation of the ERK 1/2, JNK, and p38-MAPK via ROS production indicated its potential to produce oxidative stress via mitochondrial damage in neurodegenerative disorders [38]. The association between CPF exposure and Parkinson's disease mostly has been investigated using SH-SY5Y cells. Treatment with 0, 25, 50, 100 , and $200 \mu \mathrm{M}$ CPF induced activation of p38-MAPK, JNK, and ERK, leading to an elevation in the expression of inflammatory genes including COX-2 and TNF- $\alpha$. Additionally, CPF stimulated the nuclear translocation of NF- $\mathrm{kB}$. Moreover, Rosiglitazone (RGZ), a peroxisome proliferator-activated receptor-gamma (PPAR- $\gamma$ ) agonist, was also used to prevent CPF-induced neuronal cell death and it was found that RGZ inhibited NF- $\mathrm{kB}$ expression through blocking p38-MAPK and JNK signaling activation [34]. CPF also caused PD by inducing MAPK-mediated translocation of dynamin-related protein 1 (Drp1) to the mitochondria and initiated mitochondrial fission and induced mitochondrial impairment that eventually caused mitochondrial membrane potential dissipation [39]. An elevation of phospho-Drp1 expression was observed in SH-SY5Y cells exposed to CPF [39].

It is known that Drp1 is necessary for the translocation of p53 into the mitochondria after CPF-increased ROS production. Blocking the Drp1 function-inhibited CPF caused mitochondrial-dependent apoptosis by interaction with p53 [35]. Ki et al. showed JNK- and p38-mediated expression of COX-2 in SH-SY5Y cells that were exposed to CPF [5]. They found further that the inhibitors of JNK and p38-MAPK improved CPF-increased COX-2 expression but that the inhibitor of ERK1/2 signal transmission had no effect on COX-2. Moreover, CPF has been hypothesized to cause neuronal apoptosis by increasing oxidative stress and COX-2 expression mediated by JNK and p38-MAPK signaling pathways. CPF also induced COX-2-mediated cytotoxicity regardless of the activation of the ERK1/2 signaling pathway [5]. In addition, chronic exposure to OPCs caused delayed neuropsychiatric disorders, and a mechanism underlying the delayed neurotoxicity induced by CPF can be the inhibition of ERK1/2 signaling activation. In this context, it was shown that phosphorylation of ERK1/2 during a 96-h exposure to $10 \mu \mathrm{M} \mathrm{CPF}$ occurred but that withdrawal after $48 \mathrm{~h}$ of exposure to this agent caused ERK1/2 signal inhibition, which delayed toxicity of CPF in primary rats hippocampal neurons [40].

Treatment with two activators of ERK1/2, such as nerve growth factor (NGF) and carbachol, inhibited the delayed neurotoxicity induced by CPF, which shows the influence of the inhibition of ERK1/2 phosphorylation on the delayed neurotoxicity caused by CPF [40]. Moreover, Caughlan et al. [41] have shown that CPF causes mitochondrial dysfunction and apoptosis in primary cortical neurons that have been cultured since the 17th day of embryonic life or in newborn rats. In this context, CPF increased the phosphorylation of ERK1/2 and of p38-MAPKs and CPF was unable to induce total JNK but activated a partial pool of JNK in the nucleus and induced c-Jun phosphorylation. The authors also suggested that the ERK1/2 and JNK signal activation induced apoptosis but that the activation of p38-MAPKs prevented apoptosis in cortical neurons exposed to CPF. Another CPF-induced developmental neurotoxicity is the disruption of cytoskeletal proteins, and neurite retraction in mouse N2a neuroblastoma cells is associated with a transient increase in NFH phosphorylation and ERK1/2 pathway activation [42]. It was reported that CPF exposure $(5 \mathrm{mg} / \mathrm{kg}$, daily) in substantia nigra (SN) in young adults with PND induced 11-14 dopaminergic neuronal damage in SN after activation of the inflammatory response by p65-NF- $\mathrm{BB}$ and p38-MAPK signaling pathways in the nigrostriatal system [43]. 
A study by Lazar et al. [44] showed a temporary increase in ERK1/2 activity and no modification to JNK in the hippocampus and cortex of male rats that were exposed to $80 \mu \mathrm{g} / \mathrm{kg}$ sarin after $6 \mathrm{~h}$. After $24 \mathrm{~h}$, an increase in the expression of Bax, a decrease in the ERKs, and an increase in the activity of JNK in the frontal cortex were observed. They suggested that the rapid increase in the activity of ERK1/2 without changing the JNK can show a mechanism of "first reaction" that temporarily inhibits apoptosis. Administration of sarin $(0.4 \mathrm{mg} / \mathrm{kg})$ or soman $(4.0 \mathrm{mg} / \mathrm{kg})$ to young rats increased the levels of tyrosine-phosphorylated proteins in the cytosol fraction of the brain, and JNK activation was found in the cytosol. In addition, JNK activation occurred after tyrosine kinase phosphorylation, which indicates that the activation of tyrosine kinase plays a major role in the neurotoxicity of Sarin and soman [45]. Pejchal and coworkers [46] have shown the expression of activated p38-MAPK signaling and activated MAPK transcription factors c-jun, c-myc, and elk-1 in cerebellar granula cells of rats after soman exposure, suggesting that, 14 days after soman poisoning, expression of p38-MAPK and c-myc was increased while c-jun and elk-1 expression did not change. Indeed, it has been suggested that delayed activation of p38-MAPK may be responsible for soman's neurotoxic effects [46]. They also examined the expression of phosphorylated p38-MAPK and Elk-1, c-jun, and c-myc in the cerebellar Purkinje cells of rats after soman exposure [46]. Interestingly, an increase in activated p38-MAPK and c-myc expression was observed 2 weeks after exposure to soman while the expression of activated elk-1 and c-jun was not changed 14 days after poisoning. Chang [47] reported that bilateral injection of $10 \mathrm{nmol}$ Mevinphos (Mev) into the rostral ventrolateral medulla (RVLM) of rats during brain stem death did not affect overall ERK1/2 but that phosphorylation of ERK1/2 in Thr202 and Tyr204 was stimulated. They further demonstrated the effect of Mevinphos (Mev, $10 \mathrm{nmol}$ ) on JNK and p38-MAPK in the rostral ventrolateral medulla (RVLM) of rats during experimental brainstem death, suggesting that Mev had no effect on the total amount of JNK, p38-MAPK, MAP2K4, and MAP2K6. However, Mev increased the phosphorylation of JNK in Thr183 and Tyr185, of p38-MAPK in Thr180 and Tyr182, of MAP2K4 in Ser257 and Thr261, and of MAP2K6 in Ser207 and Thr211 in RVLM during the pro-life phase of brain stem death. In addition, the phosphorylation of ATF-2 in Thr71 and of c-Jun in Ser73 in RVLM was also increased during this phase Chan et al. [48]. Furthermore, Chan et al. [49] have shown that Mev induced pro-life brainstem death via NO produced by NOS I in the Rostral Ventrolateral Medulla (RVLM), followed by stimulation of the soluble guanylyl cyclase/cGMP/PKG cascade. Further, it was shown that Bis (pinacolylmethyl) phosphonate (BPMP) induced the ERK signaling pathway to cause vacuolation in mitochondria in cultured rat astrocytes, and the authors suspected that the activated Ras/Raf-1/ERK signaling pathway was involved in modulating central cardiovascular function through NOS I/PKG upregulation [50].

\section{Organophosphorus Compound-Induced Cardiovascular Diseases are Mediated by MAPK Signaling}

It has been reported that cardiomyocyte survival and death are regulated by extracellular ligands, cytokines, and growth factors that bind to cell surface receptors and induce intracellular specific signal transduction pathways [51]. Cardiac dysfunction usually occurs as a consequence of inflammatory, oxidative stress, and apoptosis mechanisms mediated by MAPK signaling pathways, and ERK, JNK, and p38-MAPK activation has been demonstrated in heart failure models [51]. Furthermore, the effects of DZN, phenyl-saligenin-phosphate (PSP), and CPF and their toxic metabolites (diazoxone and CPF-oxone) on $\mathrm{H} 9 \mathrm{c} 2$ cardiomyoblasts were investigated. Forty-eight $\mathrm{h}$ after exposure to DZN, diazoxone, or CPF-oxone $(200 \mu \mathrm{M})$, no cytotoxicity was found in H9c2 cells [51]. However, CPF induced cardiotoxicity in $\mathrm{H} 9 \mathrm{c} 2$ at a dose of over $100 \mu \mathrm{M}$. Phenyl-saligenin phosphate (PSP) induced cytotoxicity in mitotic and differentiated $\mathrm{H} 9 \mathrm{c} 2$ cells by activating JNK1/2 signaling but not ERK1/2 signaling, suggesting the proapoptotic role of PSP for the induction of cell death [51]. 


\section{Organophosphorus Compound-Induced Respiratory Diseases are Mediated by MAPK Signaling}

Chronic obstructive pulmonary disease (COPD) is one of the most important respiratory diseases in which an increase in activated MAPK signaling is found in bronchial epithelial cells, alveolar macrophages, and pulmonary lymphocytes. Further, activated p38-MAPK is involved in local and systemic inflammation in COPD [52]. It has been reported that cell-based defense mechanisms mediated by dendritic cells play a major role in respiratory immunology and that dendritic cells potentially act on the first immune response in the respiratory system [52]. They further indicated that exposure to dimethoate or CPF reduced phosphorylation of Akt 1, Akt 2, Akt, and ERK 2 in human dendritic cells. In this context, dimethoate significantly decreased phosphorylation of the heat shock protein (HSP 27) and CPF slightly decreased its activity. However, dimethoate or CPF had no effect on p38-MAPK or the JNK [52]. Protein kinases including Akt or ERK are responsible for cell survival, which could be inhibited by OPCs, leading to an increase in inflammatory cytokines such as IL-1 $\beta$ and IL- 6 and causing pulmonary complications [52].

\section{Organophosphorus Compound-Induced Hepatotoxicity is Mediated by MAPK Signaling}

The activated MAPKs signaling contributes to hepatic metabolic processes. The liver modulates the metabolism of glucose and lipids. Pathophysiological conditions such as diabetes, obesity, and fatty liver disease associated with disturbed liver functions. In addition, stress stimulates the activation of hepatic MAPKs, which leads to a disorder of insulin action and lipid metabolism. In this context, OPCs can influence the balance of MAPK signaling pathways in liver metabolism and can contribute to metabolic disorder [53]. Further, treatment of HepG2 cells with enantiomers of isocarbophos (ICP) upregulated Bax expression and downregulated Bcl-2 expression, leading to apoptosis. It was found that (-)-ICP induces a change in the $\mathrm{Bax} / \mathrm{Bcl}-2$ ratio and hepatotoxicity by the sustained activation of JNK [53]. The addition of tributyl phosphate (TBP) and tris (2-butoxy ethyl) phosphate (TBEP) to HepG2 produced ROS overproduction and caused mitochondrial and p53-mediated apoptosis via activation of JNK and ERK1/2 pathways by TBP and activation of the JNK pathway by TBEP [54].

\section{Organophosphorus Compound-Induced Nephrotoxicity is Mediated by MAPK Signaling}

Recent studies have shown that the MAPK/ERK signaling pathways play a major role in nephrogenesis and lead to differentiation of the nephrogenic mesenchyme. Moreover, an imbalance in MAPK signaling pathways causes several illnesses, such as cancers [55]. Interestingly, it has been reported that the development of kidney cells is caused by MAPK signaling and that an imbalance in the MAPK signaling pathways, especially in the nephron precursors, leads to a disturbance in nephron differentiation [55]. In addition, Tris-(2-chloroethyl)-phosphate (TCEP) with 0.01 and $1 \mathrm{mg} / \mathrm{L}^{-1}$ significantly increased the phosphorylation of JNK and reduced the expression of Bcl-2 and ClAP-2. In fact, TCEP also increased the expression of caspase- 3 and caspase- 9 in primary cultured proximal renal tubule cells [55].

\section{Organophosphorus Compound-Induced Reproductive Toxicity is Mediated by MAPK Signaling}

A large body of evidence has demonstrated a link between the dysfunction of the MAPK signaling pathways and the dysregulation of reproductive function [56]. In addition, the toxic effect of OPs on the reproductive system was also determined. The toxic effect of CPF and the metabolites 3,5,6-trichloro-2-pyridinol (TCP) and CPF-oxone was investigated on human placental choriocarcinoma cells (JAR), and JAR cells exposed to CPF (3-250 $\mu \mathrm{M}$ for 24, 48, and $72 \mathrm{~h}$ ) had reduced the cell viability in a dose-dependent manner [56]. Further, CPF caused the loss of mitochondrial potential, DNA fragmentation, and upregulation of FAS mRNA. In this context, the addition of JNK, MEK, and PI3K inhibitors could not affect cell death. However, the p38-MAPK inhibitor (SB202190) significantly increased cell death. The results showed that activation of the p38-MAPK signaling 
pathway had a protective effect against CPF-induced cytotoxicity, and the p38-MAPK inhibitor might influence the isoform of p38-MAPK and might contribute to the activation of the survival signaling pathways [57]. CPF and CPF-oxone activated ERK44/42 signaling in both wild-type (CHOK1) and human muscarinic receptor-expressing ovarian cells of the Chinese hamster (CHO-M2). CPF-Oxone increased the activation of the ERK 44/42 pathway in CHOK1 2- to 3-fold control cells, depending on dose and time. Further, CPF-Oxon activated ERK 44/42 signaling in CHOK1 cells by P13-K, PKC, and MEK [57]. The same group also showed that diacylglycerol (DAG) induced the activation of ERK 44/42 in the ovary of the Chinese hamster (CHOK1). Pretreatment of CHOK1 cells with CPF-oxone or a carbamate increased the effect of DAG on the activation of ERK44/42 in a dose- and time-dependent manner, suggesting that inhibition of DAG lipase activity by CPF-oxone altered DAG metabolism and induced activation of the ERK 44/42 signaling pathway [58]. In another study by Lim et al., the effects of trichlorfon on the proliferation and apoptosis of porcine trophicotoderm ( $\mathrm{pTr}$ ) and uterine luminal epithelial cells ( $\mathrm{pLE}$ ) were investigated [59]. Trichlorfon prevented the proliferation of pTr and pLE cells, which led to apoptosis, loss of mitochondrial membrane potential, and DNA fragmentation. In addition, trichlorfon reduced the phosphorylation of $\mathrm{pTr}$ and pLE cells. Trichlorfon temporarily stimulated several molecular signaling proteins such as P70S6K, P90RSK, S6, JNK, and p38-MAPK, and inhibition of the ERK1/2, JNK, and p38-MAPK signaling pathways by trichlorfon reduced proliferation compared to each inhibitor alone in $\mathrm{pTr}$ cells. In addition, inhibition of ERK1/2 and p38-MAPK reduced proliferation of pLE cells, and this reduction was more pronounced when trichlorfon was combined with U0126 (ERK-inhibitor) or p38-MAPK inhibitors. The results indicated that trichlorfon had a synergic antiproliferative effect with the MAPK inhibitor on pLE and pTr cells during early pregnancy [59].

\section{Organophosphorus Compound-Induced Cancer is Mediated by MAPK Signaling}

It has been reported that OPCs can affect the immune system, which in turn can alter the differentiation and subversion of abnormal cells, thereby assessing the risk of cancer. Natural killer (NK) cells are an important component of the immune system and can interfere with tumor- and virus-infected cells, and the risk of cancer and infection can increase if the function of NK cells is impaired [60]. In this context, OPCs can disrupt the function of NK cells by activating MAPKs. Suriyo et al. investigated the inhibition of colorectal adenocarcinoma $\mathrm{H} 508$ cells with dose-dependent CPF $(5-100 \mu \mathrm{M})$ treatment and found that the EGFR/ERK1/2 signaling pathway contributes to CPF-induced growth of colorectal adenocarcinoma H508 cells [60]. In addition, CPF $(50 \mu \mathrm{M})$ caused cell death in human breast cancer cell lines MDA-MB-231 and MCF-7 by the altered redox imbalance mediated by ERK1/2 phosphorylation and the antioxidant system [61]. In another study by Park et al. [62], CPF-induced ROS production caused damage to the mitochondria and led to the swallowing of mitochondria in autophagous double-membrane vesicles. In addition, CPF caused a stabilization of protein kinase1 (PINK1) on the outer mitochondrial membrane, which led to an increase in parkin recruitment from the cytoplasm into the abnormal mitochondria, suggesting that PINK1 stabilization was modulated by ROS-induced JNK and ERK1/2 activation. In this context, DZN $\left(10^{-4}\right.$ to $\left.10^{-5} \mathrm{M}\right)$ for $24 \mathrm{~h}$ caused time-dependent cell death and reduced phosphorylated ERK2 in a dose-dependent manner, but phosphorylation of Raf-1, an upstream ERK molecule in the Ras-ERK cascade, could not affect cell death time [63]. Indeed, exposure of SH-SY5Y cells to non-neuropathic OPCs (paraoxone; $100 \mu \mathrm{M}$ ) increased MAPK activity while neuropathic OPCs (PSP; $0.01,0.1$, and $1.0 \mu \mathrm{M}$ ) inhibited activation of this pathway for $4,8,24$, and $48 \mathrm{~h} \mathrm{[64].}$

\section{Organophosphorus Compounds-Induced Hyperglycemia are Mediated by MAPK Signaling}

It is known that environmental pollutants are the main factors involved in diabetes and its complications. Studies have shown a link between exposure to OPCs and the occurrence of diabetes [65]. Furthermore, Yuan et al. [65] investigated the effects of omethoate $(0.5,1$, and $2 \mathrm{mg} / \mathrm{kg}$, PO, 60 days) on liver insulin signaling in 60 male male mice. It was observed that a high dose of omethoate increased 
the expression levels of both NF-кB and p38-MAPK and that its mean dose increased the expression of p38-MAPK. Additionally, Zhang et al. pointed out that omethoate $(1.5,3$, and $6 \mathrm{mg} / \mathrm{kg}$ body through the stomach for 2 months) increased MDA, IL-6, and TNF- $\alpha$ levels and decreased SOD and GPx activities in the right thigh muscles of rats by activating JNK, $\mathrm{p} 38-\mathrm{MAPK}$, and master transcription factor NF- $\mathrm{kB}$ in the right thigh muscles, leading to insulin resistance. ERK1/2 is a major factor involved in insulin signaling, and an increase in these levels disrupts the insulin signaling pathway [66]. In a study by Mense et al., CPF and cyfluthrin significantly increased the levels of activated ERK1/2 in primary human fetal astrocytes, suggesting that CPF and cyfluthrin increased the inflammation markers IL-6 and GFAP similar to the signaling component ERK1/2 [67].

\section{Organophosphorus Compound-Induced Dyslipidemia is Mediated by MAPK Signaling}

It has been reported that the effect of OPCs on lipid metabolism is controversial. In this context, exposure to DZN disturbed lipid metabolism by altered MAPK signaling pathways. In addition, subacute DZN (15 mg/kg, PO) on the regulation of lipid metabolism, ERK, and expression of the low-density lipoprotein receptor (LDLr) in rat liver was evaluated. DZN significantly increased cholesterol, triglyceride, and LDL levels. Additionally, DZN reduced the activated ERK1/2 and LDLr transcripts, suggesting that DZN caused dyslipidemia and increased the expression of LDLr by inhibiting the ERK signaling pathway [68].

\section{Conclusions}

It is known that exposure to OPCs causes apoptosis through activation of ERK, JNK, and p38-MAPK signaling pathways. The members of the MAPK family appear to be affected differently by each OPC, depending on the cell type. In addition, MAPKs protect cell survival or induce equilibrium and can distinguish cell death between antiapoptotic and proapoptotic signals transmitted by ERK, JNK, and p38-MAPK signaling pathways (Figure 1).

The present review suggests that OPCs may induce apoptosis by interrupting the modulation of the MAPK signaling pathway. The activation of MAPKs in the target organs has a significant effect on the toxicity of OPCs. These compounds induce apoptosis and oxidative stress by disrupting the downregulation of Nrf2 and the equilibrium of phosphorylation of Erk, JNK, and p38-MAPK in tissues from animal and in vitro models. In addition, Erk, JNK, and p38-MAPK have pro- and antiapoptotic effects triggered by OPC-induced tissue damage. Moreover, MAPK signal transduction has both inhibitory and stimulatory effects on apoptosis, depending on cell type, stimulating factor, and latency of MAPK signaling activation. In particular, MAPK has a modulating effect on numerous downstream molecules, including transcriptional and translational components, cell cycle molecules, kinases leading to cell proliferation, cell cycle arrest, migration, differentiation, and apoptosis. These multiple downstream targets, cell type, and cell cycle-specific molecular cross-talk or kinetics and time of activation can cause the complexity of MAPK effects on apoptosis. Moreover, their balance ultimately determines the fate of the cells. However, the new findings could also clarify the controversial data on the various effects of OPCs, including their effect on blood glucose and lipid profile obtained in different cell types and animal models exposed to different OPCs.

It was found that some antioxidants with beneficial effects against toxic damage induced by OPCs could regulate the MAPK signaling pathways. Chemical antioxidants such as vitamin C and E, melatonin, $\mathrm{N}$-acetylcysteine, etc. as well as flavonoids including curcumin, quercetin, berberine, etc. may be able to combat against OPC toxicity by modulating MAPK signaling.

In summary, the effect of OPCs in the initiation and progression of various diseases may be related to their effect on the regulation of MAPK signaling pathways. Studies need to be performed to determine the effect of the antidote of OPCs on MAPK signaling to find more suitable therapeutic approaches. 


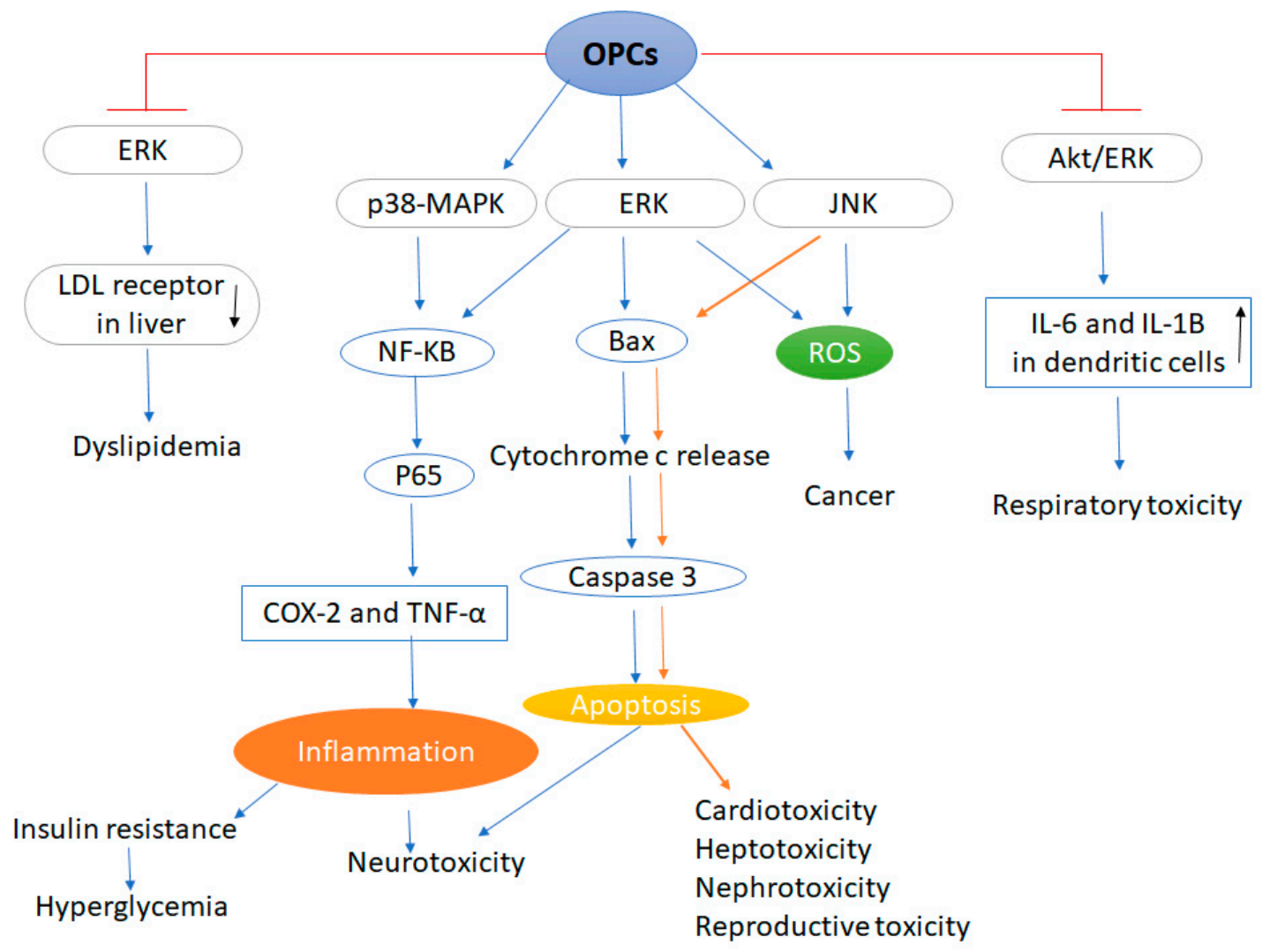

Figure 1. Organophosphorus compounds induced various diseases mediated by MAPK signaling. Abbrivations: OPCs: Organophosphate compounds, ERK: Extracellular signal-regulated protein kinase, LDL: Low density lipoprotein, MAPKs: Mitogen-activated protein kinases, NF-K $\beta$ : Nuclear transcription factor kappa- $\beta$, COX-2: Cyclooxygenase-2, TNF- $\alpha$ : Tumor necrosis factor alpha, ROS: Reactive oxygen species, Akt: Protein kinase B, JNK: c-Jun NH2-terminal kinase. Blue arrows indicate the association between OPCs exposure, MAPK signaling and neurotoxicity, hyperglycemia and dyslipidemia. $(\uparrow)$ : Increase, $(\downarrow)$ : Decrease. Brown arrows indicate the association between OPCs exposure, MAPK signaling and cardiotoxicity, hepatotoxicity, nephrotoxicity and reproductive toxicity.

Author Contributions: T.F., M.S., and S.S. designed study. All authors contributed to the collection of data, to the writing of the manuscript, and to designing tables and figures. S.S., M.S., and C.B. revised the manuscript. All authors have read and agreed to the published version of the manuscript.

Funding: This research received no external funding.

Conflicts of Interest: The authors declare no conflict of interest.

\section{Abbreviations}

AChE

Akt

AP-1

ASK1

ATF2

BPMP

CAT

CHO-M2
Acetylcholinesterase

Protein kinase B

Activator protein 1

Apoptosis-signal-regulating kinase 1

Activating transcription factor 2

Bis (pinacolylmethyl) phosphonate

Catalase

Chinese hamster 


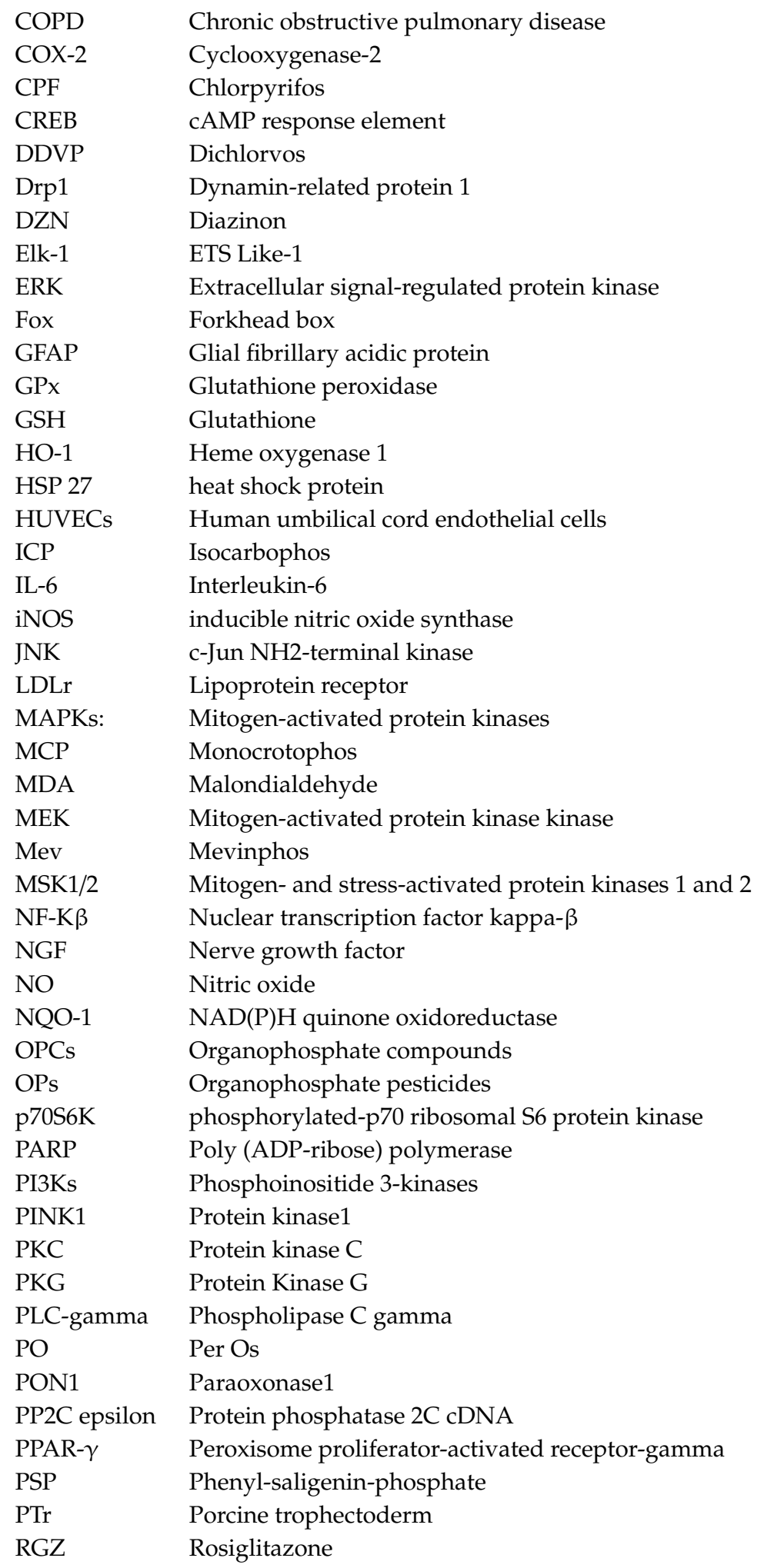




$\begin{array}{ll}\text { ROS } & \text { Reactive oxygen species } \\ \text { RVLM } & \text { Rostral ventrolateral medulla } \\ \text { Ser73 } & \text { Phospho-c-Jun } \\ \text { SN } & \text { Substantia nigra } \\ \text { SOD } & \text { Superoxide dismutase } \\ \text { TCEP } & \text { Tris-(2-chloroethyl)-phosphate } \\ \text { TCP } & \text { 3,5,6-trichloro-2-pyridinol } \\ \text { TDCPP } & \text { Tris(1,3-dichloro-2-propyl)phosphate } \\ \text { Thr180/Tyr182 } & \text { Phospho-p38 MAPK } \\ \text { Thr261 } & \text { Phospho-SEK1/MKK } \\ \text { TNF- } \alpha & \text { Tumor necrosis factor alpha } \\ \text { Trx } & \text { Thioredoxin }\end{array}$

\section{References}

1. Vanova, N.; Pejchal, J.; Herman, D.; Dlabkova, A.; Jun, D. Oxidative stress in organophosphate poisoning: Role of standard antidotal therapy. J. Appl. Toxicol. 2018, 38, 1058-1070. [CrossRef] [PubMed]

2. Andersen, J.K. Oxidative stress in neurodegeneration: Cause or consequence? Nat. Med. 2004, 10 (Suppl. 7s), S18-S25. [CrossRef] [PubMed]

3. Guignet, M.; Dhakal, K.; Flannery, B.M.; Hobson, B.A.; Zolkowska, D.; Dhir, A.; Bruun, D.A.; Li, S.; Wahab, A.; Harvey, D.J.; et al. Persistent behavior deficits, neuroinflammation, and oxidative stress in a rat model of acute organophosphate intoxication. Neurobiol. Dis. 2019, 133, 104431. [CrossRef] [PubMed]

4. Sárközy, M.; Kovács, Z.Z.; Kovács, M.G.; Gáspár, R.; Szúcs, G.; Dux, L. Mechanisms and modulation of oxidative/nitrative stress in type 4 cardio-renal syndrome and renal sarcopenia. Front. Physiol. 2018, 9, 1648. [CrossRef] [PubMed]

5. Ki, Y.W.; Park, J.H.; Lee, J.E.; Shin, I.C.; Koh, H.C. JNK and p38 MAPK regulate oxidative stress and the inflammatory response in chlorpyrifos-induced apoptosis. Toxicol. Lett. 2013, 218, 235-245. [CrossRef]

6. McCain, J. The MAPK (ERK) Pathway: Investigational Combinations for the Treatment Of BRAF-Mutated Metastatic Melanoma. Pharm. Ther. 2013, 38, 96-108.

7. Aggeli, I.K.; Gaitanaki, C.; Lazou, A.; Beis, I. Activation of multiple MAPK pathways (ERKs, JNKs, p38-MAPK) by diverse stimuli in the amphibian heart. Mol. Cell Biochem. 2001, 221, 63-69. [CrossRef]

8. Guo, Y.J.; Pan, W.W.; Liu, S.B.; Shen, Z.F.; Xu, Y.; Hu, L.L. ERK/MAPK signalling pathway and tumorigenesis. Exp. Therap. Med. 2020, 19, 1997-2007. [CrossRef]

9. Paton, E.L.; Turner, J.A.; Schlaepfer, I.R. Overcoming Resistance to Therapies Targeting the MAPK Pathway in BRAF-Mutated Tumours. J. Oncol. 2020, 2020, 14. [CrossRef]

10. Adler, V.; Yin, Z.; Fuchs, S.Y.; Benezra, M.; Rosario, L.; Tew, K.D.; Pincus, M.R.; Sardana, M.; Henderson, C.J.; Wolf, C.R.; et al. Regulation of JNK signaling by GSTp. EMBO J. 1999, 18, 1321-1334. [CrossRef]

11. Selim, K.A.; Abdelrasoul, H.; Aboelmagd, M.; Tawila, A.M. The Role of the MAPK Signaling, Topoisomerase and Dietary Bioactives in Controlling Cancer Incidence. Diseases 2017, 5, 13. [CrossRef] [PubMed]

12. Gosselin, R.E.; Smith, R.P.; Hodge, H.C. Clinical Toxicology of Commercial Products; Williams \& Wilkins: Philadelphia, PA, USA, 1984; ISBN 13:978-0683036329.

13. Figueroa-Villar, J.D.; Petronilho, E.C.; Kuca, K.; Franca, T.C.C. Review about structure and evaluation of reactivators of Acetylcholinesterase inhibited with neurotoxic organophosphorus compounds. Curr. Med. Chem. 2020. [CrossRef] [PubMed]

14. Budzinski, H.; Couderchet, M. Environmental and human health issues related to pesticides: From usage and environmental fate to impact. Environ. Sci. Pollut. Res. 2018, 25, 14277-14279. [CrossRef] [PubMed]

15. Baselt, R.C. Disposition of toxic drugs and chemicals in man. J. Anal. Toxicol. 2018, 42, 139. [CrossRef]

16. Peter, J.V.; Sudarsan, T.I.; Moran, J.L. Clinical features of organophosphate poisoning: A review of different classification systems and approaches. Indian J. Crit. Care Med. 2014, 18, 735-745. [CrossRef]

17. Namba, T. Cholinesterase inhibition by organophosphorus compounds and its clinical effects. Bull. World Health Organ. 1971, 44, 289-307. 
18. Alahakoon, C.; Dassanayake, T.L.; Gawarammana, I.B.; Sedgwick, E.M.; Weerasinghe, V.S.; Abdalla, A.; Roberts, M.S.; Buckley, N.A. Prediction of organophosphorus insecticide-induced intermediate syndrome with stimulated concentric needle single fibre electromyography. PLoS ONE 2018, 13, e0203596. [CrossRef]

19. Ventura, C.; Zappia, C.D.; Lasagna, M.; Pavicic, W.; Richard, S.; Bolzan, A.D.; Monczor, F.; Nunez, M.; Cocca, C. Effects of the pesticide chlorpyrifos on breast cancer disease. Implication of epigenetic mechanisms. J. Steroid Biochem. Mol. Biol. 2019, 186, 96-104. [CrossRef]

20. Echiburu-Chau, C.; Calaf, G.M. Rat lung cancer induced by malathion and estrogen. Int. J. Oncol. 2008, 33, 603-611. [CrossRef]

21. Kaur, S.; Singh, S.; Chahal, K.S.; Prakash, A. Potential pharmacological strategies for the improved treatment of organophosphate-induced neurotoxicity. Can. J. Physiol. Pharmacol. 2014, 92, 893-911. [CrossRef]

22. Delfino, R.T.; Ribeiro, T.S.; Figueroa-Villar, J.D. Organophosphorus compounds as chemical warfare agents: A review. J. Braz. Chem. Soc. 2009, 20, 407-428. [CrossRef]

23. Farkhondeh, T.; Samarghandian, S. Antidotal effects of curcumin against agents-induced cardiovascular toxicity. Cardiovasc. Hematol. Disord. Drug Targets 2016, 16, 30-37. [CrossRef] [PubMed]

24. Samarghandian, S.; Azimi-Nezhad, M.; Farkhondeh, T. Immunomodulatory and antioxidant effects of saffron aqueous extract (Crocus sativus L.) on streptozotocin-induced diabetes in rats. Indian Heart J. 2017, 69, 151-159. [CrossRef] [PubMed]

25. Samarghandian, S.; Azimi-Nezhad, M.; Shabestari, M.M.; Azad, F.J.; Farkhondeh, T.; Bafandeh, F. Effect of chronic exposure to cadmium on serum lipid, lipoprotein and oxidative stress indices in male rats. Interdiscip. Toxicol. 2015, 8, 151-154. [CrossRef]

26. Samarghandian, S.; Azimi-Nezhad, M.; Borji, A.; Hasanzadeh, M.; Jabbari, F.; Farkhondeh, T.; Samini, M. Inhibitory and cytotoxic activities of chrysin on human breast adenocarcinoma cells by induction of apoptosis. Pharmacogn. Mag. 2016, 12, S436.

27. Valko, M.; Leibfritz, D.; Moncol, J.; Cronin, M.T.; Mazur, M.; Telser, J. Free radicals and antioxidants in normal physiological functions and human disease. Int. J. Biochem. Cell Biol. 2007, 39, 44-84. [CrossRef]

28. Wu, B.; Wang, F.; Zhou, J.; Hou, Y.; Hong, G.; Zhao, G.; Ge, Y.; Liu, Y.; Qiu, Q.; Lu, Z. [Effect of PON1 overexpression on mouse diaphragmatic muscle cells injury caused by acute dichlorvos poisoning]. Zhonghua Yi Xue Za Zhi 2015, 95, 2955-2959. [CrossRef]

29. Guo, R.; Chen, L.; Lian, J.; Wu, B.; Hong, G.; Ge, Y.; Liu, Y.; Qiu, Q.; Lu, Z. [The protective effect of regulation of paraoxonase 1 gene on liver oxidative stress injury induced by dichlorvos poisoning in mice]. Zhonghua Wei Zhong Bing Ji Jiu Yi Xue 2015, 27, 285-290. [CrossRef]

30. Jahan, S.; Kumar, D.; Singh, S.; Kumar, V.; Srivastava, A.; Pandey, A.; Rajpurohit, C.S.; Khanna, V.K.; Pant, A.B. Resveratrol Prevents the Cellular Damages Induced by Monocrotophos via PI3K Signaling Pathway in Human Cord Blood Mesenchymal Stem Cells. Mol. Neurobiol. 2018, 55, 8278-8292. [CrossRef]

31. Zhong, X.; Qiu, J.; Kang, J.; Xing, X.; Shi, X.; Wei, Y. Exposure to tris (1, 3-dichloro-2-propyl) phosphate (TDCPP) induces vascular toxicity through Nrf2-VEGF pathway in zebrafish and human umbilical vein endothelial cells. Environ. Pollut. 2019, 247, 293-301. [CrossRef]

32. Batista, J.E.; Sousa, L.R.; Martins, I.K.; Rodrigues, N.R.; Posser, T.; Franco, J.L. Data on the phosphorylation of p38MAPK and JNK induced by chlorpyrifos in Drosophila melanogaster. Data Brief 2016, 9, 32-34. [CrossRef] [PubMed]

33. Shou, L.; Bei, Y.; Song, Y.; Wang, L.; Ai, L.; Yan, Q.; He, W. Nrf2 mediates the protective effect of edaravone after chlorpyrifos-induced nervous system toxicity. Environ. Toxicol. 2019, 34, 626-633. [CrossRef] [PubMed]

34. Lee, J.E.; Park, J.H.; Jang, S.J.; Koh, H.C. Rosiglitazone inhibits chlorpyrifos-induced apoptosis via modulation of the oxidative stress and inflammatory response in SH-SY5Y cells. Toxicol. Appl. Pharm. 2014, 278, 159-171. [CrossRef] [PubMed]

35. Xia, Z.; Dickens, M.; Raingeaud, J.; Davis, R.J.; Greenberg, M.E. Opposing effects of ERK and JNK-p38 MAP kinases on apoptosis. Science 1995, 270, 1326-1331. [CrossRef] [PubMed]

36. Tian, J.; Xue, B.; Hu, J.; Li, J.; Cheng, X.; Hu, J.; Li, F.; Chen, Y.; Li, B. Exogenous substances regulate silkworm fat body protein synthesis through MAPK and PI3K/Akt signaling pathways. Chemosphere 2017, 171, $202-207$. [CrossRef] [PubMed]

37. Esquivel-Sentíes, M.; Barrera, I.; Ortega, A.; Vega, L. Organophosphorous pesticide metabolite (DEDTP) induces changes in the activation status of human lymphocytes by modulating the interleukin 2 receptor signal transduction pathway. Toxicol. Appl. Pharmacol. 2010, 248, 122-133. [CrossRef] [PubMed] 
38. Lee, J.E.; Park, J.H.; Shin, I.C.; Koh, H.C. Reactive oxygen species regulated mitochondria-mediated apoptosis in PC12 cells exposed to chlorpyrifos. Toxicol. Appl. Pharm. 2012, 263, 148-162. [CrossRef]

39. Park, J.H.; Ko, J.; Hwang, J.; Koh, H.C. Dynamin-related protein 1 mediates mitochondria-dependent apoptosis in chlorpyrifos-treated SH-SY5Y cells. Neurotoxicology 2015, 51, 145-157. [CrossRef]

40. Tan, D.-H.; Peng, S.-Q.; Wu, Y.-L.; Wang, Y.-M.; Lu, C.-F.; Ding, W.; Wang, Q.-X.; Yan, C.-H. Chlorpyrifos induces delayed cytotoxicity after withdrawal in primary hippocampal neurons through extracellular signal-regulated kinase inhibition. Biol. Pharm. Bull. 2009, 32, 1649-1655. [CrossRef]

41. Caughlan, A.; Newhouse, K.; Namgung, U.; Xia, Z. Chlorpyrifos induces apoptosis in rat cortical neurons that is regulated by a balance between p38 and ERK/JNK MAP kinases. Toxicol. Sci. 2004, 78, 125-134. [CrossRef]

42. Zhang, J.; Dai, H.; Deng, Y.; Tian, J.; Zhang, C.; Hu, Z.; Bing, G.; Zhao, L. Neonatal chlorpyrifos exposure induces loss of dopaminergic neurons in young adult rats. Toxicology 2015, 336, 17-25. [CrossRef] [PubMed]

43. Lazar, S.; Egoz, I.; Brandeis, R.; Chapman, S.; Bloch-Shilderman, E.; Grauer, E. Propagation of damage in the rat brain following sarin exposure: Differential progression of early processes. Toxicol. Appl. Pharm. 2016, 310, 87-97. [CrossRef] [PubMed]

44. Niijima, H.; Nagao, M.; Nakajima, M.; Takatori, T.; Iwasa, M.; Maeno, Y.; Koyama, H.; Isobe, I. The effects of sarin-like and soman-like organophosphorus agents on MAPK and JNK in rat brains. Forensic Sci. Int. 2000, 112, 171-178. [CrossRef]

45. Pejchal, J.; Osterreicher, J.; Kassa, J.; Tichy, A.; Mokry, J. Activation of mitogen activated protein kinase (MAPK) pathways after soman poisoning in rat cerebellar granule neurons. J. Appl. Toxicol. 2008, 28, 689-693. [CrossRef] [PubMed]

46. Pejchal, J.; Osterreicher, J.; Kassa, J.; Tichy, A.; Micuda, S.; Sinkorova, Z.; Zarybnicka, L. Soman poisoning alters p38 MAPK pathway in rat cerebellar Purkinje cells. J. Appl. Toxicol. 2009, 29, 338-345. [CrossRef] [PubMed]

47. Chang, A.Y. Pro-life role for c-Jun N-terminal kinase and p38 mitogen-activated protein kinase at rostral ventrolateral medulla in experimental brain stem death. J. Biomed. Sci. 2012, 19, 96. [CrossRef]

48. Chan, S.H.; Sun, E.Y.; Chang, A.Y. Extracellular signal-regulated kinase 1/2 plays a pro-life role in experimental brain stem death via MAPK signal-interacting kinase at rostral ventrolateral medulla. J. Biomed. Sci. 2010, 17, 17. [CrossRef]

49. Chan, S.H.; Chan, J.Y.; Hsu, K.S.; Li, F.C.; Sun, E.Y.; Chen, W.L.; Chang, A.Y. Amelioration of central cardiovascular regulatory dysfunction by tropomyocin receptor kinase B in a mevinphos intoxication model of brain stem death. Br. J. Pharm. 2011, 164, 2015-2028. [CrossRef]

50. Isobe, I.; Maeno, Y.; Nagao, M.; Iwasa, M.; Koyama, H.; Seko-Nakamura, Y.; Monma-Ohtaki, J. Cytoplasmic vacuolation in cultured rat astrocytes induced by an organophosphorus agent requires extracellular signal-regulated kinase activation. Toxicol. Appl. Pharm. 2003, 193, 383-392. [CrossRef]

51. Felemban, S.G.; Garner, A.C.; Smida, F.A.; Boocock, D.J.; Hargreaves, A.J.; Dickenson, J.M. Phenyl Saligenin Phosphate Induced Caspase-3 and c-Jun N-Terminal Kinase Activation in Cardiomyocyte-Like Cells. Chem. Res. Toxicol. 2015, 28, 2179-2191. [CrossRef]

52. Schäfer, M.; Koppe, F.; Stenger, B.; Brochhausen, C.; Schmidt, A.; Steinritz, D.; Thiermann, H.; Kirkpatrick, C.J.; Pohl, C. Influence of organophosphate poisoning on human dendritic cells. Chem. Biol. Interact. 2013, 206, 472-478. [CrossRef] [PubMed]

53. Liu, H.; Liu, J.; Xu, L.; Zhou, S.; Li, L.; Liu, W. Enantioselective cytotoxicity of isocarbophos is mediated by oxidative stress-induced JNK activation in human hepatocytes. Toxicology 2010, 276, 115-121. [CrossRef] [PubMed]

54. Ren, G.; Hu, J.; Shang, Y.; Zhong, Y.; Yu, Z.; An, J. Tributylphosphate (TBP) and tris (2-butoxyethyl) phosphate (TBEP) induced apoptosis and cell cycle arrest in HepG2 cells. Toxicol. Res. 2017, 6, 902-911. [CrossRef] [PubMed]

55. Ren, X.; Han, H.J.; Lee, Y.J.; Lee, S.H.; Ng, H.Y.; Chae, K.-J.; Kim, I.S. Proapoptotic effect of a micropollutant (tris-(2-chloroethyl)-phosphate) at environmental level in primary cultured renal proximal tubule cells. J. Water Health 2012, 10, 522-530. [CrossRef]

56. Saulsbury, M.D.; Heyliger, S.O.; Wang, K.; Round, D. Characterization of chlorpyrifos-induced apoptosis in placental cells. Toxicology 2008, 244, 98-110. [CrossRef] 
57. Bomser, J.; Casida, J.E. Activation of extracellular signal-regulated kinases (ERK 44/42) by chlorpyrifos oxon in Chinese hamster ovary cells. J. Biochem. Mol. Toxicol. 2000, 14, 346-353. [CrossRef]

58. Bomser, J.A.; Quistad, G.B.; Casida, J.E. Chlorpyrifos oxon potentiates diacylglycerol-induced extracellular signal-regulated kinase (ERK 44/42) activation, possibly by diacylglycerol lipase inhibition. Toxicol. Appl. Pharm. 2002, 178, 29-36. [CrossRef]

59. Lim, W.; An, Y.; Yang, C.; Bazer, F.W.; Song, G. Trichlorfon inhibits proliferation and promotes apoptosis of porcine trophectoderm and uterine luminal epithelial cells. Environ. Pollut. 2018, 242, 555-564. [CrossRef]

60. Suriyo, T.; Tachachartvanich, P.; Visitnonthachai, D.; Watcharasit, P.; Satayavivad, J. Chlorpyrifos promotes colorectal adenocarcinoma $\mathrm{H} 508$ cell growth through the activation of EGFR/ERK1/2 signaling pathway but not cholinergic pathway. Toxicology 2015, 338, 117-129. [CrossRef]

61. Ventura, C.; Venturino, A.; Miret, N.; Randi, A.; Rivera, E.; Núñez, M.; Cocca, C. Chlorpyrifos inhibits cell proliferation through ERK1/2 phosphorylation in breast cancer cell lines. Chemosphere 2015, 120, 343-350. [CrossRef]

62. Park, J.H.; Ko, J.; Park, Y.S.; Park, J.; Hwang, J.; Koh, H.C. Clearance of damaged mitochondria through PINK1 stabilization by JNK and ERK MAPK signaling in chlorpyrifos-treated neuroblastoma cells. Mol. Neurobiol. 2017, 54, 1844-1857. [CrossRef] [PubMed]

63. Aluigi, M.G.; Guida, C.; Falugi, C. Apoptosis as a specific biomarker of diazinon toxicity in NTera2-D1 cells. Chem. Biol. Interact. 2010, 187, 299-303. [CrossRef] [PubMed]

64. Pomeroy-Black, M.; Ehrich, M. Organophosphorus compound effects on neurotrophin receptors and intracellular signaling. Toxicol. Vitr. 2012, 26, 759-765. [CrossRef] [PubMed]

65. Yuan, W.; Ling, L.Y.; Zhu, M.F.; Lian, H.B.; Ning, Z.C.; Han, X.S.; Ping, R.S. Effects of Omethoate on Liver Insulin Signaling in Mice. Biomed. Environ. Sci. 2018, 31, 627. [CrossRef]

66. Zhang, Y.; Ren, M.; Li, J.; Wei, Q.; Ren, Z.; Lv, J.; Niu, F.; Ren, S. Does omethoate have the potential to cause insulin resistance? Environ. Toxicol. Pharmacol. 2014, 37, 284-290. [CrossRef]

67. Mense, S.M.; Sengupta, A.; Lan, C.; Zhou, M.; Bentsman, G.; Volsky, D.J.; Whyatt, R.M.; Perera, F.P.; Zhang, L. The common insecticides cyfluthrin and chlorpyrifos alter the expression of a subset of genes with diverse functions in primary human astrocytes. Toxicol. Sci. 2006, 93, 125-135. [CrossRef]

68. Lari, P.; Rashedinia, M.; Abnous, K.; Hosseinzadeh, H. Crocin improves lipid dysregulation in subacute diazinon exposure through ERK1/2 pathway in rat liver. Drug Res. 2014, 64, 301-305. [CrossRef] 